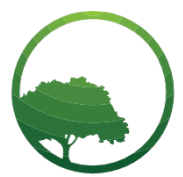

Research in Business \& Social Science

IJRBS VOL 8 NO 5 ISSN: 2147-4478

\title{
Shareholder loyalty and firm value creating outcomes in Kenya
}

\author{
Amos M. Kimunya ${ }^{a}{ }^{*}$,Amos Njuguna ${ }^{b}$, Francis Wambalaba ${ }^{c}$ \\ ${ }^{a, b, c}$ Chandaria School of Business, United States International Uinversity Africa, Nairobi, Kenya
}

\begin{tabular}{l} 
A R T I C L E I N F O \\
\hline Article history: \\
Received 15 July 19 \\
Received in revs. form 05 August 19 \\
Accepted 10 August 19 \\
\hline Keywords: \\
Shareholder Loyalty \\
Shareholder Engagement \\
Firm Value Creation \\
Institutional Investor \\
JEL Classification: \\
G32 \\
M40 \\
N27
\end{tabular}

\begin{abstract}
A B S T R A C T
The study aimed at examining the effect of shareholder loyalty on firm value-creating outcomes in Kenya. The study used a sample of 117 institutional shareholders in listed firms in Kenya. Data was collected through questionnaires and analyzed using descriptive statistics such as mean, mode, and median and inferential statistics including factor analysis, regression, and analysis of variance (ANOVA). The study concluded that shareholder loyalty has no significant effect on firm value-creating outcomes. The study contributes to the literature on shareholder engagement, particulary on shareholder loyalty from a Kenyan angle. Shareholders are advised to consider their initial cost of investment, costs, and penalties on exit and impact on their business interests with the firm as they decide on their voice or exit actions.
\end{abstract}

(C) 2019 Bussecon International Academy. Hosting by SSBFNET. All rights reserved. Peer review under responsibility of Bussecon International Academy \& SSBFNET.

\section{Introduction}

Shareholders, being rational profit maximisers, are keen to enhance value from their investments and are now more than before engaging with their management (Becht, Franks, Grant, \& Wagner, 2017) to influence decision making towards value creating outcomes (Denes, Karpoff, \& McWilliams, 2017). This shareholder engagement or activism includes use of shareholder loyalty, alongside 'voice' and 'exit' strategies to influence management towards actions that will create value, or avoid further deterioration. Accordingly, a shareholder faced with discontent can choose between voicing concerns, exiting, or staying loyal, depending on the barriers and costs associated with each (Chung \& Talaulicar, 2010; Hirschman, 1970). Shareholder loyalty is described by Hirschman (1970) as a special attachment to a product or association that obscures one from taking the rational decision to exit, in the hope that recuperation will occur. This study applies the definition to shareholders and their relationship with their firms.

The main trigger for shareholder engagement has been corporate losses and associated mistrust of professional managers from recent global financial crises, leading to increased agitation by investors - especially passive institutional investors with limited exit options such as pension funds - to be included in the management and oversight of firms (Clark \& Hebb, 2004; Gillan \& Starks, 2007; Ingley, Mueller, \& Cocks, 2011; Marler \& Faugère, 2010). The shift towards shareholder activism has been increasingly reported in the U.K. in the 1970s, mainly facilitated by the legal environment (Black \& Coffee Jr., 1994; Crespi \& Renneboog, 2010) and in the U.S. from the mid-1980s (Gillan \& Starks, 2007). In Africa there is also growing incidences of shareholder activism as noted in Nigeria arising from corporate challenges (Amao \& Amaeshi, 2008), while corporate governance and shareholder activism has been shown to be intertwined with the political system (Adegbite, Amaeshi, \& Amao, 2012). Investor activism has also developed in South Africa, mainly driven by environment, social and governance issues (Yamahaki \& Frynas, 2016) and the growing monitoring needs of institutional investors (Viviers \& Smit, 2015).

\footnotetext{
* Corresponding author. Tel: +254722518801 ORCID ID: 0000-0001-9529-3333

Peer review under responsibility of Bussecon International Academy.

(C) 2019 Bussecon International. Hosting by SSBFNET- Center for Strategic Studies in Business \& Finance. All rights reserved.

https://doi.org/10.20525/ijrbs.v8i5.313
} 
Inspite of the growing importance of, and scholarly attention to, shareholder engagement, there has been a paucity of studies on the subject, and more particularly on effect of shareholder loyalty on firm value creating outcomes in developing countries such as Kenya. There are challenges on concurrence of shareholder engagement, its value to corporations, and even whether it is desirable due to differences in shareholder interest, costs and complexity (Goranova \& Ryan, 2014; Kim \& Schloetzer, 2013). Further, the implication of regional and legal differences and developments necessitate isolated contextualised reviews, including by the variables, as there is no global standard (Goranova \& Ryan, 2014). An understanding of the significance of shareholder loyalty on firm value creating outcomes will assist shareholders as they decide on engagement strategies to use.

The paper is presented in four sections. The introduction covers the background information on shareholder loyaty and its effects on firm value creating outcomes, followed by theoretical and empirical review of the literature. Section three is on research methodology while section four presents the results and findings of the study and discussion, and lastly the conclusion, and recommendations of the study.

\section{Literature Review}

The study was anchored on the Shareholder theory of the firm which provides an appropriate starting point to help understand the overarching motivations of shareholders, which is to maximize economic value (Pfarrer, 2010). Previously, Jensen and Meckling (1976), in a modified theory of the firm, the agency theory, had reemphasized profit and value maximization motives and primacy of the shareholder, while taking cognizance of, and including managerial behavior, agency costs, and ownership structure. It also borrows from Hirschman's treatise, Exit, Voice and Loyalty, on reactions to deterioration of products or services (Hirschman, 1970). The concepts of exit, voice and loyalty have been subsequently incorporated into literature regarding shareholders and their confrontations with management over their firms' performance (Donald, 2005). In between the extreme of voice and exit engagers are the shareholders who have loyalty, with special attachment to the firm, and who would rather maintain the status quo hoping that some actions will be taken to restore any deterioration in value, before taking the voice route, and eventually, the exit option if all else fails (Goodman, Louche, van Cranenburgh, \& Arenas, 2014; Hirschman, 1970). These loyalists include long-term investors looking for value and growth, especially the index-linked pension funds managers who do not have the easy Exit option, and are otherwise constrained on Voice in order not to antagonize potential clients (Clark \& Hebb, 2004; Hirschman, 1970; McCahery, Sautner, \& Starks, 2016).

Hirschman (1970) identifies Loyalty as having a moderating effect on both exit and voice. It is most effective when there are limited or no barriers to exit as it is the only mechanism that can delay exit while giving either voice or recovery a chance. Hirschman (1970) suggests that loyalty delays exit actions, and even when voice is not the preferred alternative, it gives room for innovative solutions to be found, which could avert exit losses while leading to recuperation. Hirschman (1970) further observes that managers, in their short-term interests to entrench themselves, and remain undisturbed by complaints or desertions could create institutional devices and mechanisms to repress both voice and exit, by locking in loyalists, in ways that are acceptable to society, which includes the severity of initiation. Accordingly, a loyalist who paid a high cost of ownership, thus suffering severe initiation is unlikely to leave the group, even when they experience deterioration. Borrowing from cognitive dissonance theory, Hirschman (1970) argues that such a member is likely to get into self-deception, fighting the realization (cognition) of the loss of their investment (act). They may not only delay voice but will fight hard to prove they were not wrong in investing in the first place. Eventually, however, when they find their voice, they may come out stronger especially in private dialogues. While Pergola and Verreault (2011) observe that loyal engagers are likely to side with management, Goodman et al. (2014) suggests that loyal shareholders are likely to favor voice over exit in order to preserve their investment, and indeed loyalty acts as a moderator between the exit and voice strategies. Further, McNulty and Nordberg (2016) based on a review of literature on engagement, observe that shareholders may take the loyalist route while seeking alternatives.

Edmans and Manso (2011) also note that dispersed and small shareholders are likely to consider the cost of the two extreme strategies of voice which they may not afford, or losses to their investments should they exit and choose to be free riders, which negatively affects exit. This is corroborated by Hirschman (1970) who observed that where the cost of disengaging is excessive, or there are penalties in terms of transaction costs or taxes that negate exit, a loyalist may not disengage. Hirschman further suggested that this also applies where some consider that the firm will become worse when they leave, and hence they hang on and support even after they eventually leave. This loyalty will further be influenced by the intensity of attachment and historical ties with an organization, and there is a feeling that like in the past when it has gone through cycles of boom and bust it will recover. This is especially common with sentimental feelings of founder members of a firm.

The study aimed at examining the effect of shareholder loyalty on firm value creating outcomes in Kenya, and test the null hypothesis: Shareholder loyalty has no significant effect on the firm value creating outcomes.

\section{Research and Methodology}

This study adopted a post-positivist philosophical worldview and limited itself to quantitative methods. It adopted a descriptive correlational research design. The population of the study consisted of 166 institutional investors in listed firms at the Nairobi Securities Exchange as of September 2016, and a sample size of 117 using stratified random sampling. The institutional shareholders 
sample was determined as the maximum sample size using the widely-used and simplified Yamane (1967) formula (as cited by Singh \& Masuku, 2014) given as $\mathrm{n}=\mathrm{N} /\left(1+\mathrm{N}^{*} \mathrm{e}^{2}\right)$, where $\mathrm{n}=$ sample size, $\mathrm{N}=$ population in this case 166 shareholders, and $\mathrm{e}=$ precision level of $+/-5 \%$ (e2=0.0025). Data was collected using self-administered questionnaires, and then analyzed using descriptive statistics of frequency and percentage distribution, mean, mode and median. Additionally, inferential data analysis methods were used which included factor analysis and ANOVA, while multiple linear regression was used to test the hypotheses.

\section{Result and Discussion}

The effect of shareholder loyalty on firm value creating outcomes was measured using one variable measured on a five-point Likert scale questions, with 1 being strongly disagree and 5 being strongly agree, and results displayed on Table 2 below. The respondents were asked seven questions relating to the shareholders' decision to stay even though they were dissatisfied. The model score for "the consideration that the initial cost of investment is too high to lose", "the hope that the cause for dissatisfaction will be corrected", and "that exit may affect other business relationships with the firm", was 4, indicating that most respondents agree that these points influence their loyalty to the firm. The results show that the modal score for "having sentimental attachment to the firm", the "consideration that the size of the investment would affect the overall value of shares", "reluctance to exit the position because clients may infer that the investor picked the wrong stock", and "costs of exit", was 1, indicating that most respondents neither agree nor disagree with the statements.

An analysis of the means indicates that the "initial cost of the investment being too high" had a mean of 3.13, while the "hope that the shareholders' cause of dissatisfaction would be addressed" had a mean of 3.00. "Exit may affect your other business relationships with the firm" had a mean of 2.99 , followed by "the consideration of the value of the shares of the investee being material to affect the overall value ranking" with a mean of 2.92. The fifth factor affecting shareholder loyalty was "costs and penalties related to exit", with a mean of 2.86. In addition, factor analysis was carried out to determine the contribution of each of the factors to shareholder loyalty. The results are presented in Table 1, indicating the KMO and Bartlett's test statistic that shows the suitability of the data in carrying out factor analysis. The results indicated a KMO statistic of 0.755 and a statistically significant Bartlett's test of p-value 0.000 , which is less than 0.05 and supports factor analysis.

Table 1: Shareholder loyalty factor analysis

\begin{tabular}{|c|c|c|}
\hline Kaiser-Meyer-Olkin Measure of Sampling Adequacy. & & .755 \\
\hline \multirow[t]{3}{*}{ Bartlett's Test of Sphericity } & Approx. Chi-Square & 113.720 \\
\hline & df & 21 \\
\hline & Sig. & .000 \\
\hline
\end{tabular}

Source: Authors

The principal component method was applied to the seven items measuring shareholder loyalty to obtain one factor measuring shareholder loyalty to be used in regression analysis. The item's individual factor loadings to shareholder loyalty were obtained while retaining all the items to avoid bias due to the small sample size. An analysis of the factor loadings showing that exit may affect the shareholders' relationship with the firm had a loading of 0.716 .

The initial cost of investment as too high to lose had a loading of 0.706 , and the size of the shareholder's investment being material to affect the overall value of shares achieved a loading of 0.661 . The shareholder's hope that the cause of their dissatisfaction would be corrected had a loading of 0.656 , while costs and penalties related to exit had a loading of 0.640 . At the lower end, sentimental attachment to the firm had a factor loading of 0.545 , while institutional investors not exiting because clients may infer they picked the wrong stock had a loading of 0.541 . 
Table 2: Shareholder loyalty

\begin{tabular}{|c|c|c|c|c|}
\hline & Mean & Median & Mode & $\begin{array}{l}\text { Factor } \\
\text { Loading }\end{array}$ \\
\hline Exit may affect your other business relationships with the firm & 2.99 & 3 & 4 & 0.716 \\
\hline You consider the initial cost of investment as too high to lose & 3.13 & 3 & 4 & 0.706 \\
\hline $\begin{array}{l}\text { You consider the size of your investment material to affect the overall } \\
\text { value of shares }\end{array}$ & 2.92 & 3 & 3 & 0.661 \\
\hline You are hopeful the cause of dissatisfaction will be corrected & 3 & 3 & 4 & 0.656 \\
\hline There are costs and penalties related to exit & 2.86 & 3 & 3 & 0.64 \\
\hline You have sentimental attachment to the firm & 2.81 & 3 & 3 & 0.545 \\
\hline $\begin{array}{l}\text { As an institutional investor with a large position, might be reluctant to } \\
\text { exit that position because clients may infer that you picked the wrong } \\
\text { stock }\end{array}$ & 2.79 & 3 & 3 & 0.541 \\
\hline
\end{tabular}

Source: Authors

\section{Comparison of means of shareholder loyalty based on the investment horizon}

Comparison of means of Shareholder Loyalty based on the different investment horizons was carried out to determine whether the means varied statistically for the respondents who preferred either the short term, medium or long-term investment. Since the investment horizon consisted of more than two levels, a one-way ANOVA was conducted at 95\% confidence level. The null hypothesis was that the means of shareholder loyalty for the different investment horizons are statistically the same. Table 3 displays the ANOVA results. The results indicated a p-value of 0.685 , which is greater than 0.05 , hence the failure to reject the null hypothesis and concluding that the means for shareholder loyalty based on the investment horizons are statistically the same at $95 \%$ confidence level.

Table 3: ANOVA for shareholder loyalty based on investment horizon

\begin{tabular}{lccc}
\hline Investment Horizon & N & Mean & F-Statistic (p-value) \\
\hline Short 1-6 months & 15 & -0.11 & $0.48(\mathrm{p}=\mathbf{0 . 6 8 5}>0.05)$ \\
Medium 6 -24 months & 23 & -0.09 & \\
Long term Over 2yrs & 32 & 0.10 & \\
\hline
\end{tabular}

Source: Authors

\section{Regression analysis for shareholder loyalty and firm value creating outcomes}

\section{Internal validity}

Before carrying out factor analysis on shareholder loyalty, Cronbach's alpha statistic was calculated to determine internal validity of the Likert scale questions measuring shareholder loyalty. The Cronbach's alpha statistic lies between 0 and 1 , with values closer to 1 indicating a higher level of internal consistency. Table 4 shows the results of the Cronbach's alpha for the scale questions measuring shareholder loyalty, which indicated an alpha value of 0.76 for factors explaining shareholder loyalty.

Table 4: Cronbach's alpha on shareholder loyalty

\begin{tabular}{lll}
\hline Question & No. of items & Cronbach's Alpha \\
\hline Factors explaining Shareholder Loyalty & 7 & $\mathbf{0 . 7 6}$ \\
\hline
\end{tabular}

\section{Normality test on shareholder loyalty}

Figure 1 below shows the normal distribution plot for shareholder loyalty. The points were noted to be evenly distributed along the diagonal line, hence the conclusion that the responses on shareholder loyalty are normally distributed. 


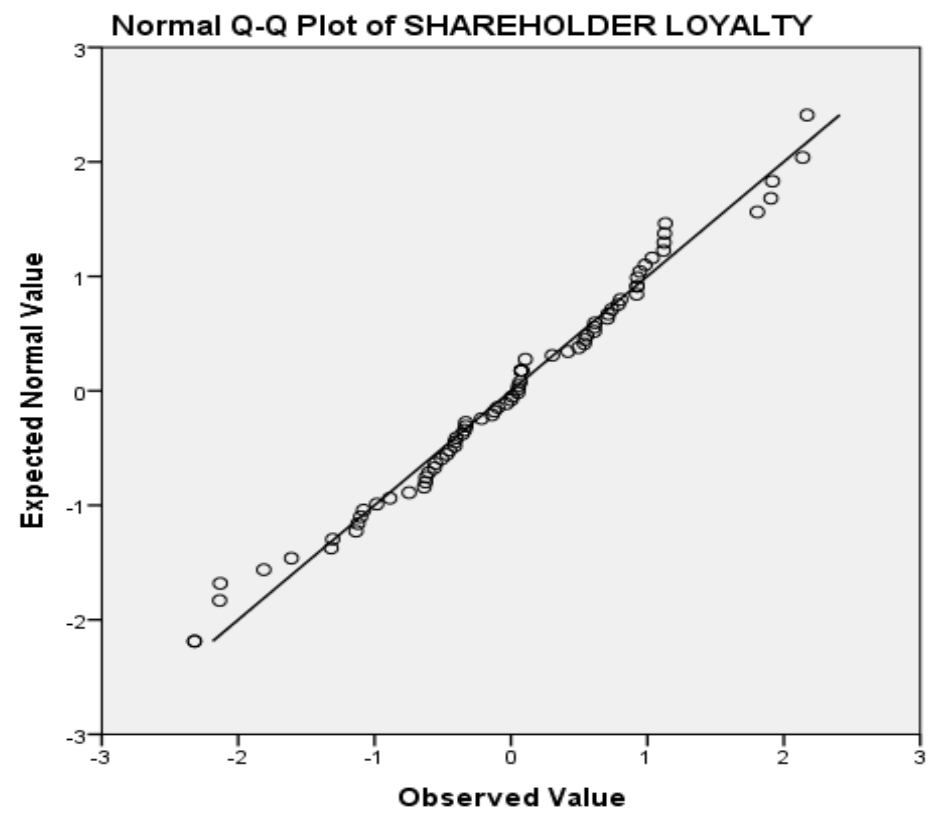

Figure 1: Normal Q-Q plot of shareholder loyalty

\section{Test for heteroskedasticity on shareholder loyalty}

An assumption of the linear regression model is that there is homoscedasticity in the residuals of the model. The residuals should therefore be evenly distributed when plotted against the dependent variable to prove the absence of heteroskedasticity. Figure 2 shows the plot of the residuals from the linear regression model between shareholder loyalty and firm value creating outcomes. The plot shows the points evenly distributed along with no clear pattern, hence the conclusion that there is no heteroskedasticity.

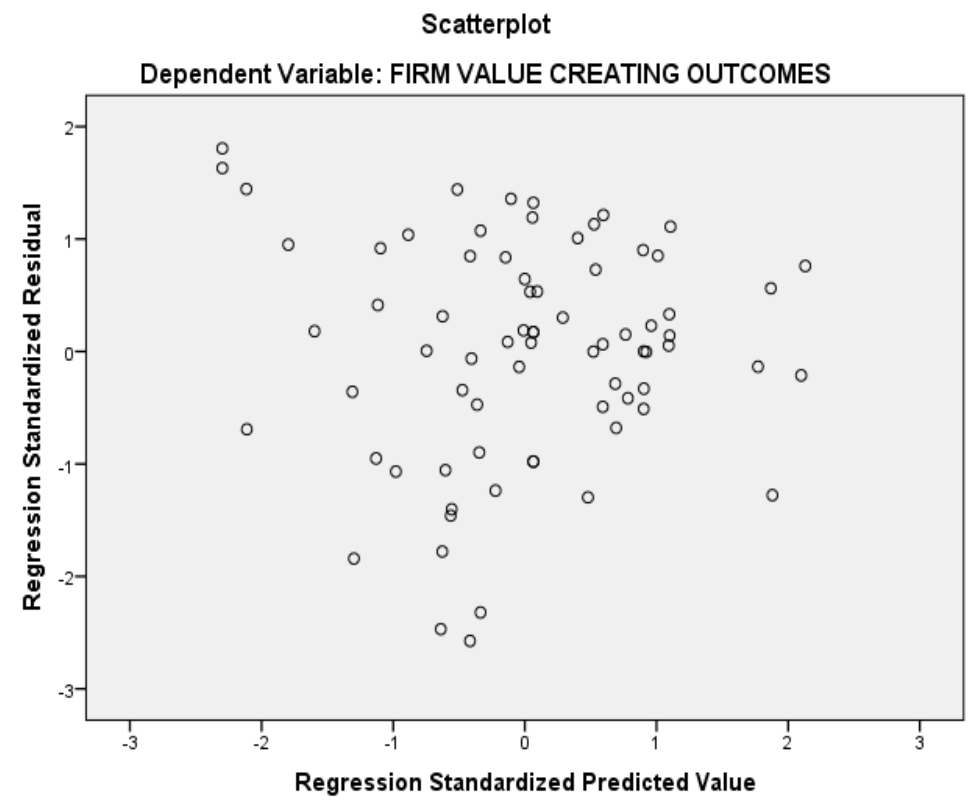

Figure 2: Test for heteroskedasticity on shareholder loyalty

\section{Regression analysis}

The factor obtained in the dimension reduction using factor analysis was used to fit a linear regression model on the data to determine the effect of shareholder loyalty on firm value creating outcomes, as presented in Table 5. The overall model fit r-square statistic indicated that shareholder loyalty contributed $4.10 \%$ of the variance in firm value creating outcomes. The analysis of variance statistic 
of 3.048 ( $p=0.085$ which is greater than 0.05 ), pointed to a statistically-insignificant regression model at $95 \%$ confidence level. The regression coefficient of shareholder loyalty of 0.201 was also statistically insignificant with a p-value of 0.085 , which is greater than 0.05 and was interpreted to mean that a unit increase in shareholder loyalty leads to a 0.201 unit increase in value of the firm.

Table 5: Regression analysis for loyalty

\begin{tabular}{lllll}
\hline Variable & B & Std. Error & t & Sig \\
\hline (Constant) & -.011 & .116 & -.098 & .922 \\
Shareholder Loyalty & .201 & .115 & 1.746 & .085 \\
F statistic (p value) & $3.048(\mathbf{0 . 0 8 5})$ & & \\
R squared & $\mathbf{0 . 0 4 1}$ & & \\
\hline
\end{tabular}

Source: Authors

The overall model for effect of shareholder loyalty on firm value creating outcomes was as represented below;

Firm value creating outcomes $=-0.011+0.201 \mathrm{X} 1$

Where; $\mathrm{X} 1=$ Shareholder loyalty

\section{Hypotheses testing for effect of shareholder loyalty on firm value creating outcomes}

The hypothesis was tested at $95 \%$ confidence level based on the results of the linear regression model whose results were presented in table 1 above. The criterion was to reject the null hypothesis if the calculated $p$-value was greater than the critical p-value of 0.05 at $95 \%$ confidence level. The null hypothesis was that Shareholder loyalty has no effect on firm value creating outcomes. The calculated p-value recorded in table 2 was 0.085 which is greater than 0.05 . This means that the null hypothesis was not rejected and the conclusion made that Shareholder loyalty has no effect on firm value creating outcomes.

\section{Discussions}

This study aimed at examining the effect of shareholder loyalty on the firm value creating outcomes. Shareholder loyalty was divided into: the high initial cost of investment, sentimental attachment, hope in correcting the cause of dissatisfaction, size of the investment being material, institutional investor, costs and penalties, and business relationships. The study finds that shareholder loyalty has no significant relationship to firm value creating outcomes. From one-way ANOVA, the regression analysis confirmed that shareholder loyalty does not significantly affect firm value creating outcomes. An analysis of the factor loadings showed that the risk that exit may affect shareholders' relationship with the firm contributed the highest to shareholder loyalty, followed by the initial cost of investment, if considered as too high to lose. This was followed by the size of the shareholders' investment being considered as material to affect the overall value of shares, and the shareholders' hope that the cause of their dissatisfaction will be corrected, while the issue of costs and penalties related to exit was fifth. At the low end, sentimental attachment to the firm and the risk that institutional investors were not exiting because clients may infer they picked the wrong stock ranked last.

The findings of the study support the findings of Goodman et al. (2014), who revealed that loyal shareholders have a special attachment to the firm and would rather maintain the status quo hoping that some actions will be taken to restore any deterioration in value. Hirschman (1970) found that shareholder loyalty is most effective when there are limited or other barriers to exit as it is the only mechanism that can delay exit while giving either voice or recovery a chance. Hirschman (1970) affirmed that loyalty delays exit actions that would distract the value of the firm and gives room for innovative solutions to be found, which could avert exit losses while leading to recuperation. From the findings of Pergola and Verreault (2011), it was observed that the loyalty engagers are likely to side with management as they seek for alternative solutions. On the other hand, Goodman et al. (2014) found that in case the deterioration persists, loyal shareholders are likely to favour voice over exit in order to preserve their investment. The study supports earlier suggestions that loyalty acts as a moderator between the exit and voice strategies.

The study found that the most critical factor that enhances shareholder loyalty is the fact that exit may affect a shareholder's other business relationships with the firm. The findings of the study agree with the findings of Hirschman (1970), who found that institutional investors with a larger portion of investment opt not to exit because if they do, their action will become worse when they leave, and hence they hang on. The study by McNulty and Nordberg (2016) found that dispersed and small shareholders are likely to consider the cost of the two extreme strategies of voice which they may not afford, or losses to their investments should they exit, and choose to be free riders. Edmans and Manso (2011) also confirmed that exit may affect shareholders' other business relationships with the firm, hence they opt to be loyal.(Edmans \& Manso, 2011)

The study in the second parameter, examined whether a high initial cost of investment would make shareholders not to exit from the firm. The study found that investors consider the initial cost of investment as too high to lose, hence they opt not to exit but be loyal to the firm. The study echoes the findings of Hirschman (1970), who asserts that a loyalist who paid a high cost of joining an ownership, thus suffering severe initiation, is unlikely to leave the group even when they experience deterioration. The author adds 
that loyal shareholders are likely to get into self-deception, fighting the realization of the loss of their investment. This is supported by Pergola and Verreault (2011) who believe that loyal shareholders may not only delay voice, but will fight hard to prove they were not wrong in investing in the first place. Hirschman (1970) adds that when the shareholders find their voice, they usually come out stronger, especially in private dialogues. McNulty and Nordberg (2016), in their study, revealed that loyalty acts as a moderator between the exit and voice strategies.

For the third most critical parameter for shareholder loyalty, the study found that shareholders who consider the size of their investment as being material to affect the overall value of shares are likely to remain loyal. This means that the exit actions by a shareholder with a material size of investment in a firm can affect the value of the firm. This finding concurs with the findings of Goodman et al. (2014), who found that shareholders with a significant number of shares in a firm may discipline the managers and firms in general if they opt to exit the firm. This forces the shareholder to engage with the management to effect their decision and by default they become loyal to the firm. The study findings agree with the findings of McCahery et al. (2016), who argue that the size of the investment is negatively related to exit as trading off a large size is likely to trigger a price fall, and the loss on exit can be unbearably high. This will automatically cause loyalty among the big shareholders. The study agrees with the findings of Pergola and Verreault (2011), who found that the size of an investment influences loyal shareholders to favour voice over exit for them to preserve their investment as they keenly seek alternative routes to solve any dispute.

In the fourth key parameter of shareholder loyalty, the study aimed at examining how shareholder loyalty is influenced by the hope that the cause of dissatisfaction will be corrected. From the study, it was confirmed that some shareholders are likely to remain loyal to the firm because they believe and are hopeful that the cause of dissatisfaction will be corrected. In business, this dissatisfaction is typically related to a company's finances or performance. The study echoes the findings in Hirschman (1970), who found shareholder loyalty as a special attachment to a firm that obscures one from taking the rational decision to exit, in the hope that recuperation will occur. The study found that those shareholders who are not so loyal are quick to engage in voice and exit and that they often feel dissatisfied with management. The findings of this study do not concur with the findings of Admati and Pfleiderer (2009), who in their study found that this kind of shareholders feel they do not benefit from their investments as much as managers and other stakeholders do, hence they are not hopeful that the cause of dissatisfaction will be corrected. The study findings diifer with those of Admati and Pfleiderer (2009), which could be due to the different investment horizons of the respondents. Goodman et al. (2014), however, note that loyalty has a limit, and as deterioration continues, hard decisions have to be made on whether to engage in voice, or exit.

\section{Conclusions}

This research study examined the effect of shareholder loyalty on the firm value creating outcomes and concluded that shareholder loyalty has no significant effect on the firm value creating outcomes, and therefore the null hypothesis was not rejected.

The study contributes to literature on shareholder engagement, particularly on shareholder loyalty from a Kenyan perspective. Shareholders are advised to consider their initial cost of investment, costs and penalties on exit and impact on their business interests with the firm as they decide on their voice or exit actions. This will avoid acrimony with their management, rushed and costly decisions, and ensure sustainable business relationships, while still pursuing positive engagement for the mutual benefit of the firm and investors.

The study also found there is limited, if any, publicly available data on engagement. This study recommends further research on the subject, expanding the sample to include other categories of investors such as the individuals and foreign investors, which were not covered by this study. Policymakers are also advised to consider development of a Kenya specific central depository of data on engagement actions, outcomes across the listed companies, borrowing from best practices in the US and UK. This will facilitate efficiency and effectiveness in future research as engagement becomes embraced in the country and the region.

\section{References}

Adegbite, E., Amaeshi, K., \& Amao, O. (2012). The politics of shareholder activism in Nigeria. Journal of Business Ethics, 105(3), 389-402. https://doi.org/10.1007/s10551-011-0974-y

Admati, A. R., \& Pfleiderer, P. (2009). The "Wall Street Walk" and shareholder activism: Exit as a form of voice. The Review of Financial Studies, 22(7), 2645-2685. https://doi.org/10.1093/rfs/hhp037

Amao, O., \& Amaeshi, K. (2008). Galvanising shareholder activism: A prerequisite for effective corporate governance and accountability in Nigeria. Journal of Business Ethics, 82(1), 119-130. https://doi.org/10.1007/s10551-007-9566-2

Becht, M., Franks, J., Grant, J., \& Wagner, H. F. (2017). Returns to hedge fund activism: An international study. Review of Financial Studies, 30(9), 2933-2971. https://doi.org/10.1093/rfs/hhx048

Black, B. S., \& Coffee Jr., J. C. (1994). Hail Britannia?: Institutional investor behavior under limited regulation. Michigan Law Review, 92(7), 1997-2087. 
Chung, H., \& Talaulicar, T. (2010). Forms and effects of shareholder activism. Corporate Governance: An International Review, 18(4), 253-257. https://doi.org/10.1111/j.1467-8683.2010.00806.x

Clark, G. L., \& Hebb, T. (2004). Pension fund corporate engagement: The fifth stage of capitalism. Industrial Relations, 59(1), 142171. https://doi.org/10.7202/009130ar

Crespi, R., \& Renneboog, L. (2010). Is (Institutional) shareholder activism new? Evidence from UK shareholder coalitions in the pre-Cadbury era. Corporate Governance: An International Review, 18(4), 274-295. https://doi.org/10.1111/j.14678683.2010.00795.x

Denes, M. R., Karpoff, J. M., \& McWilliams, V. B. (2017). Thirty years of shareholder activism: A survey of empirical research. Journal of Corporate Finance. https://doi.org/10.1016/j.jcorpfin.2016.03.005

Donald, D. C. (2005). Shareholder voice and its opponents. The Journal of Corporate Law Studies, 5(2), 1-60.

Edmans, A., \& Manso, G. (2011). Governance through trading and intervention: A theory of multiple blockholders. The Review of Financial Studies, 24(7), 2395-2428. https://doi.org/10.1093/rfs/hhq145

Gillan, S. L., \& Starks, L. T. (2007). The evolution of shareholder activism in the United States. Journal of Applied Corporate Finance, 19(1), 55-73.

Goodman, J., Louche, C., van Cranenburgh, K. C., \& Arenas, D. (2014). Social shareholder engagement: The dynamics of voice and exit. Journal of Business Ethics, 125(2), 193-210. https://doi.org/10.1007/s10551-013-1890-0

Goranova, M., \& Ryan, L. V. (2014). Shareholder activism: A multidisciplinary review. Journal of Management (Vol. 40). https://doi.org/10.1177/0149206313515519

Hirschman, A. O. (1970). Exit, voice, and loyalty: Responses to decline in firms, organizations, and states. Cambridge, MA.: Harvard University Press.

Ingley, C., Mueller, J., \& Cocks, G. (2011). The financial crisis, investor activists and corporate strategy: Will this mean shareholders in the boardroom? Journal of Management and Governance, 15(4), 557-587. https://doi.org/10.1007/s10997-010-9130-9

Jensen, M. C., \& Meckling, W. H. (1976). Theory of the firm: Managerial behavior, agency costs and ownership structure. Journal of Financial Economics, 3(4), 305-360. https://doi.org/10.1016/0304-405X(76)90026-X

Kim, J., \& Schloetzer, J. D. (2013). Global trends in board-shareholder engagement. The Conference Board Director Notes, DNV5N20(October), 1-11.

Marler, J. H., \& Faugère, C. (2010). Shareholder activism and middle management equity incentives. Corporate Governance: An International Review, 18(4), 313-328. https://doi.org/10.1111/j.1467-8683.2010.00794.x

McCahery, J. A., Sautner, Z., \& Starks, L. T. (2016). Behind the scenes: The corporate governance preferences of institutional investors. Journal of Finance, 71(6), 2905-2932.

McNulty, T., \& Nordberg, D. (2016). Ownership, activism and engagement: Institutional investors as active owners. Corporate Governance: An International Review, 24(3), 346-358. https://doi.org/10.1111/corg.12143

Pergola, T. M., \& Verreault, D. A. (2011). Motivations and potential monitoring effects of large shareholders. CORPORATE GOVERNANCE: The International Journal of Business in Society, 9(5), 551-563. https://doi.org/10.1108/14720700910998120

Pfarrer, M. D. (2010). What is the purpose of the firm?: Shareholder and stakeholder theories. In J. O’Toole \& D. Mayer (Eds.), Good business: Exercising effective and ethical leadership (pp. 86-93). Routledge.

Singh, A. S., \& Masuku, M. B. (2014). Sampling techniques \& determination of sample size in applied statistics research: An overview. International Journal of Economics, Commerce and Management, II(11), 1-22.

Viviers, S., \& Smit, E. vdM. (2015). Institutional proxy voting in South Africa: Process, outcomes and impact. South African Journal of Business Management, 46(4), 23-34.

Yamahaki, C., \& Frynas, J. G. (2016). Institutional determinants of private shareholder engagement in Brazil and South Africa: The role of regulation. Corporate Governance: An International Review, 24(5), 509-527. https://doi.org/10.1111/corg.12166 